\title{
超電導発電機用界磁巻線の安定性
}

\author{
海保 勝之, 樋口登, 石井格, 立石 裕 \\ 野村 晴彦, 名取 尚武, 新井 和昭, 関根 聖治 \\ 大西 利只，熊谷 幹夫*，饗庭 敏之** \\ 電子技術総合研究所 つくば市梅園 1-1-4 \\ * 掓東芝重電技術研究所 横浜市鶴見区末広町 $2-4$ \\ ** 秝東芝京浜事業所 横浜市鶴見区末広町 2-4 \\ （1992 年 8 月 13 日受理）
}

\section{A Study on Stabilities of Field Windings for}

Superconducting Power Generators

Katsuyuki KAIHO, Noboru HIgUCHI, Itaru IsHII, Hiroshi TATEISHI, Harehiko Nomura, Naotake NATORI, Kazuaki ARAI, Seiji Sekine,

Toshitada ONISHI, Mikio KumagaI* and Toshiyuki AIBA**

Energy Technology Division, Electrotechnical Laboratory, 1-1-4 Umezono, Tsukuba 305

* Heavy Apparatus Engineering Laboratory, Toshiba Corporation, 2-4 Suehiro-cho, Tsurumi, Yokohama 230

** Keihin Product Operations, Toshibạ Corporation, 2-4 Suehiro-cho, Tsurumi, Yokohama 230

(Received August 13, 1992)

\section{Synopsis:}

A superconducting model rotor had been constructed and a pair of test coil in the rotor was replaced after the preliminary test. The normal zone propagating velocities and the minimum propagating current were measured on this new test coil. These experimental results were compared with the caluculated results by Dresner's equation. The rotation speed dependence in experimental results were measured and well explained theoretically by Dresner's equation. The normal zone propagating velocities at the downward of helium flow were measured and the temperature rise of the conductor due to hot helium flow from upward were found out.

\section{1. 緒言}

1988 年から工業技術院の大型省エネルギー技術研 究開発プロジェクトのひとつとして，7万kW 級モデ ル超電導発電機の研究開発がスタートした。このプロ ジェクトでは，実用につながる発電機の基盤技術を確 立することを目標にしている。電子技術総合研究所で はこのプロジェクトの全体計画の中で超電導発電機用 界磁巻線（回転子マグネット）の安定性, 高遠心力場 での液体へリウムの物性・電気絶縁, 線材などの評価 研究を担当している。そこで当所では高速回転場で安 定性が試験できる装置を開発し，安定性の実験，解析 を進めてきている ${ }^{1 \sim 4)}$ 。ここでは,これまでの試験結 果を基に新たに設計製作した試験導体を用いて行った 試験結果について報告する。

\section{2. 回転マグネット実験装置の概要}

実験装置の構造は文献 2）に報告されている。2 極 （N極， $\mathrm{S}$ 極）の鞍型コイルの両極に試験用のレース トラック型コイルが配置されている。このレーストラ ック型コイルは卷替えが可能な構造となっている。レ ーストラック型コイル(以下供試コイルと呼ぶ)の常電 導相の伝播速度測定部付近の展開図と電圧タップおよ びヒータの取り付け位置をFig. 1 亿示す。電圧タップ の取り付け位置は Fig. 1 亿示すようにヒータのすぐ近 傍 $(1,2 ， 3 ４ ）$ 执よび少し離れた $(5,6,7,8)$ である。 ただし， S 極には $(7,8)$ は取り付けていない。(1, $2,3,4)$ の取り付け位置は前回までの試験と同じであ り，(5,6,7,8) は今回の試験で泠媒 (ヘリウム) の流 れの影響を見るために新たに取り付けたものである。 
29. 0 c m
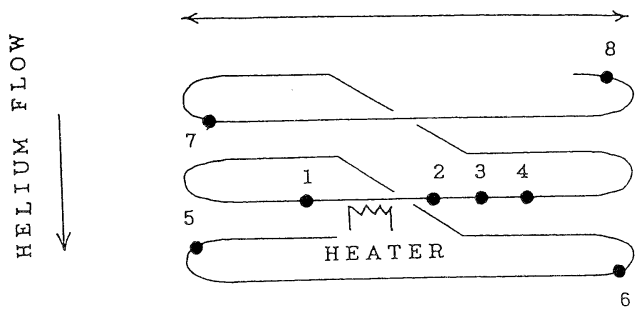

Fig. 1 Potential terminals and a heater winding on the one test coil.

これらの電生タップ間の距離は Table 1 に示すように なっている。

\section{1 供試コイルの導体の諸元}

供試コイルは $\mathrm{N}$ 極と $\mathrm{S}$ 極に取り付けが可能である。 今回は素線の構成が銅マトリックスのものと $\mathrm{CuNi}$ を 含んだいわゆる 3 層構造のものを用意した。素線の構 成と導体としての構造を Table 2 亿示す。導体の臨界 電流特性（撚り戻し素線の臨界電流を 12 倍したもの） と供試コイルの直線部（常電導相の伝播速度が測定さ れた）が経験する磁界特性を Fig. 2 に示す。

\section{3. 実験結果と考察}

\section{1 常電導相の伝播速度}

常電導相の伝播速度の測定結果の一例（N極）を
Table 1 Distance between potential terminal.

\begin{tabular}{cc}
\hline Potential lead & Distance $(\mathrm{cm})$ \\
\hline $1-2$ & 6 \\
$2-3$ & 3 \\
$3-4$ & 3 \\
$1-6$ & 44 \\
$5-6$ & 31 \\
$4-7$ & 42 \\
$7-8$ & 31 \\
\hline
\end{tabular}

Fig. 3 に示す。回転子マグネットの励磁回路は Fig. 4 のようになっている。

Fig. 3 に打いて，ヒータ投入後 $20 \mathrm{~ms}$ 程度の後まず 1-2 間の電圧が上昇し始め, 続いて 2-3，2-4 間の電圧 が上昇しているのがわかる。電压は各区間全体嫦電 導相が広がった後は急激に上昇速度が遅くなる。2-3, 2-4 の電圧の上昇速度が急激に変化する時刻の差から 常電導相の伝播速度を計算した。

また電源を遮断した後, 電流は保護抵抗に流れ減衰 をする。電流値が低くなったところでの電圧の変化の 折れ曲がりの後に各区間が超電導状態に復帰したこと が推定される。事実, 超電導状態に復帰した後に, 電 压が変化する様子はクエンチが起きていない場合とま ったく同じであった。1-2, 2-3, 2-4 の各電圧が超電

Table 2 Specification of superconductor.

\begin{tabular}{lll}
\hline Strand/Conductor & \multicolumn{1}{c}{$\mathrm{N}$ pole } & \multicolumn{1}{c}{$\mathrm{S}$ pole } \\
\hline Strand & & \\
$\quad$ Diameter & $0.7 \mathrm{~mm}$ & $0.7 \mathrm{~mm}$ \\
NbTi/Cu/CuNi & $1 / 2 / 1$ & $1 / 3 / 0$ \\
Filament dia. & $4 \mu \mathrm{m}$ & $4 \mu \mathrm{m}$ \\
$I_{\mathrm{c}}(4 \mathrm{~T})$ & $287 \mathrm{~A}$ & $278 \mathrm{~A}$ \\
Conductor & & \\
Strand num. & 12 & 12 \\
Dimension & $4.0 \times 1.3(\mathrm{~mm})$ & $4.0 \times 1.3(\mathrm{~mm})$ \\
$I_{\mathrm{c}}(4 \mathrm{~T})$ & $3,372 \mathrm{~A}$ & $3,096 \mathrm{~A}$ \\
Wet perimeter & $37 \%$ & $37 \%$ \\
\hline
\end{tabular}

$\mathrm{N}$ b T i Filaments
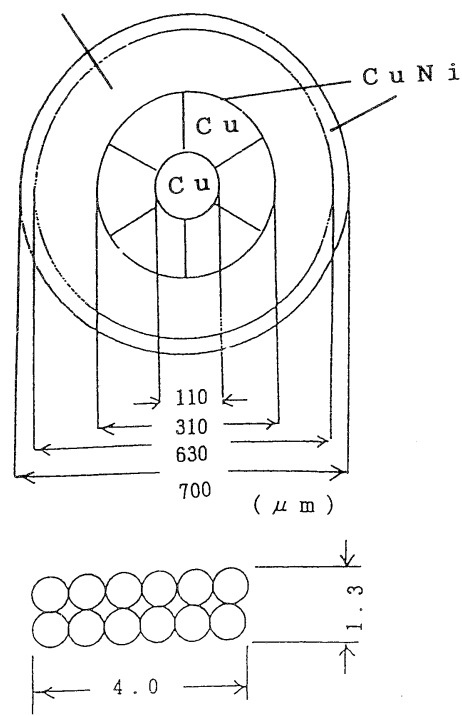

( $\mathrm{m} m$ ) 


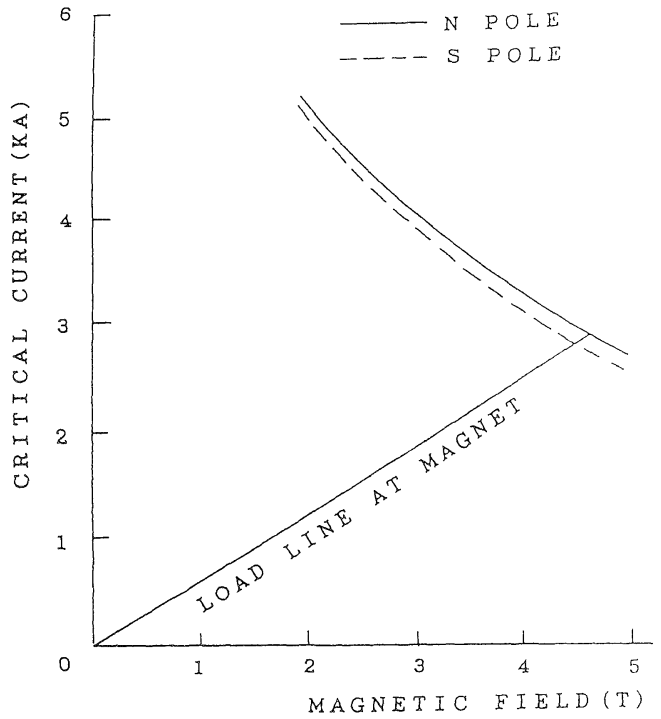

Fig. 2 Critical current and load line versus magnetic field.

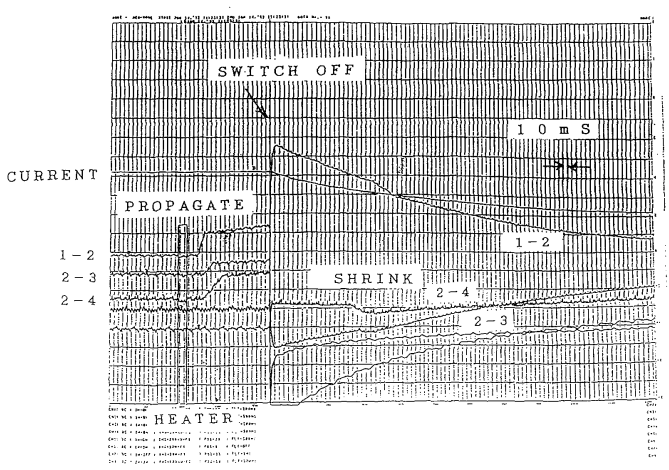

Fig. 3 Typical measured voltage profiles.

導状態に復帰するには時間差がある。この時間差から 常電導相が縮小する速度（傎の伝播速度）を計算し た。

Fig. 5 (a)，(b) は，このよらにして計算した伝播速度 の値を示したものである。

$\mathrm{N}$ 極（ 3 層構造線）の昜合，電流值が小さくなるに つれ伝播速度が回転数に依存して変化を示しているの がわかる。

Fig. 5 に拈いて実線は Dresner の理論式 (1) から 計算したものであるら。

$$
V_{\mathrm{p}}=\frac{1}{C} \sqrt{\frac{P h K}{A}} \frac{\alpha i^{2}+i-2}{\sqrt{\left(1-\frac{i}{2}\right)\left(\alpha i^{2}+\frac{i}{2}-1\right)}}
$$

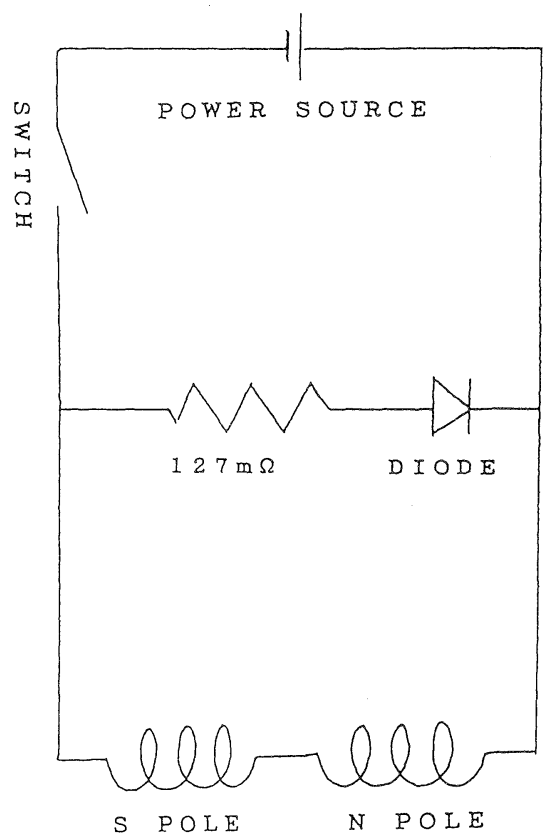

Fig. 4 Experimental circuit.

ただし， $V_{\mathrm{p}}$ は常電導相の伝播速度， $P$ は冷却周辺 長， $K, A, C$ はそれぞれ導体の熱伝導率, 断面積, 比熱, $\alpha$ は Stekly ハラメータ $\left(=I_{\mathrm{c}}^{2} \rho / A P h\left(T_{\mathrm{c}}\right.\right.$ $\left.T_{0}\right), \rho$ は常電導状態に打ける抵抗率, $i$ は通電電流之 臨界電流の比である。（1）式において各常数はTable 3 に示す值を用いた。熱伝達係数 $h$ の值は前回の垁験 時飞熱流束計測素子を用いて測定された熱流束のデー タから求めた1)。熱流束の值は発熱源の表面とへリウ ムの温度差に対して非線形な変化を示すが，ここでは 全温度範囲にわたり熱流束が温度差に比例して変化す ると近似した。このようにして求めた熱伝達係数の温

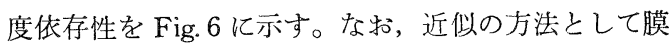
沸騰に特ける特性を全温度範囲にわたり拡張した。こ のよらにして求めた熱伝達係数の值は注涪回転数に比 例して増加していることがわかる。

以上に述べた数字を用いて計算した伝播速度の電流 依存性は，Fig. 5 に示すと括り定量的な一致は完全と はいえないが，抒执よその全体的な傾向は含っている といえよう。

$\mathrm{S}$ 極（銅マトリックス線）の場合は測定結果の数 が少なく伝播速度の回転数依存性は不明であるが， $1,500 \mathrm{~A}$ では回転速度が大きい汪ど伝播速度が小さく なることがわかる。電源を遮断した後の電流減衰過程 


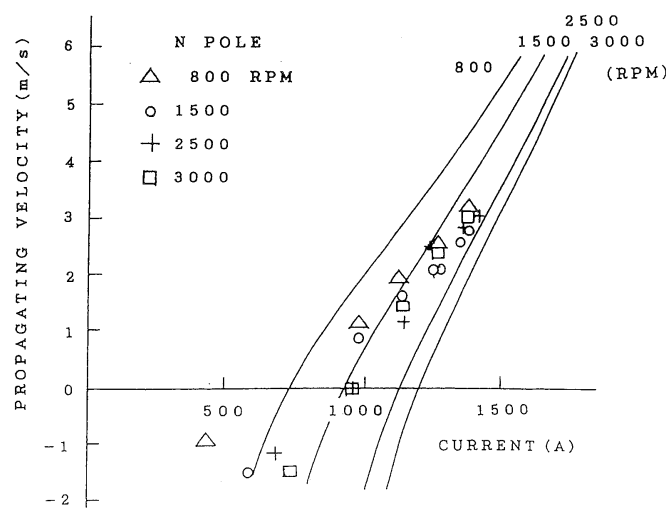

(a)

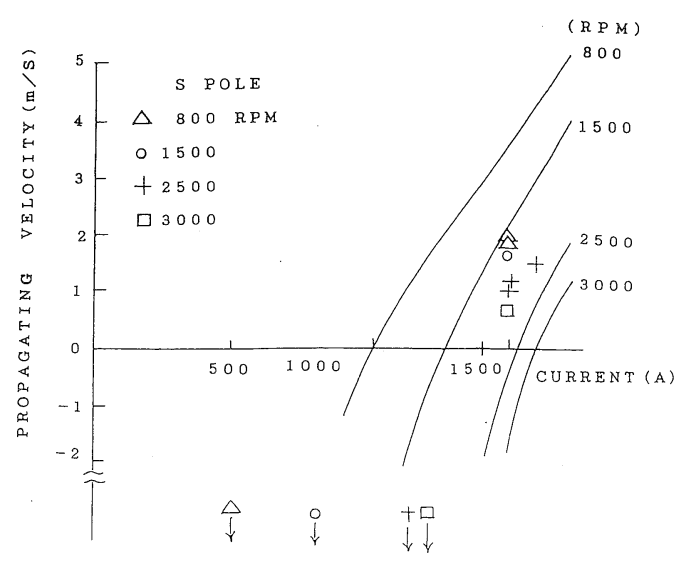

(b)

Fig. 5 (a), (b) The normal zone propagating velocities versus transport current.

に拈ける超電導状態への復帰は 1-2, 2-3, 2-4 の各電 圧に扮いて同時に起こっていた。したがって超電導状 態への復帰時の常電導相の縮小速度（負の伝播速度） が無限大であるとして図示してある。

$\mathrm{N}$ 極と $\mathrm{S}$ 極の伝播速度を比較すると， $\mathrm{S}$ 極のほうが 伝播速度が小さく，最小伝播電流が大きいことがわか る。これは超電導素線の構成からもわかるにように 極の導体の汪うが銅の量が多く，(1) 式に和ける Stekly パラメータ $\alpha$ の值が小さいためである。つま り同一の電流值に対してN極の導体の汪らが常電導部 に打けるジュール発熱の量が大きく，より熱が伝わり やすくなり伝播速度が大きくなるためである。

\section{2 最小伝播電流}

Fig. 7 は 2, 500 rpm, 1, 400A の場合に特いて, S 極にヒータを投入した後の電圧の変化を測定したもの
Table 3 Values used in the calculation of propagating velocities for the conductor.

\begin{tabular}{lll}
\hline & \multicolumn{1}{c}{ N pole } & \multicolumn{1}{c}{ S pole } \\
\hline$\rho(\Omega \mathrm{m})$ & $7.1 \times 10^{-10}$ & $3.2 \times 10^{-10}$ \\
$A\left(\mathrm{~m}^{2}\right)$ & $4.62 \times 10^{-6}$ & $4.62 \times 10^{-6}$ \\
$R\left(\Omega \mathrm{m}^{-1}\right)$ & $1.54 \times 10^{-4}$ & $0.7 \times 10^{-4}$ \\
$K\left(\mathrm{Wm}^{-1} \mathrm{~K}^{-1}\right)$ & $300 \mathrm{f}$ & $300 \mathrm{f}$ \\
$f$ & $1 / 2$ & $3 / 4$ \\
$C\left(\mathrm{Jm}^{-3} \mathrm{~K}^{-1}\right)$ & $9-12 \times 10^{3}$ & $9-12 \times 10^{3}$ \\
$P\left(\mathrm{~m}^{2}\right)$ & $3.92 \times 10^{-3}$ & $3.92 \times 10^{-3}$ \\
\hline
\end{tabular}

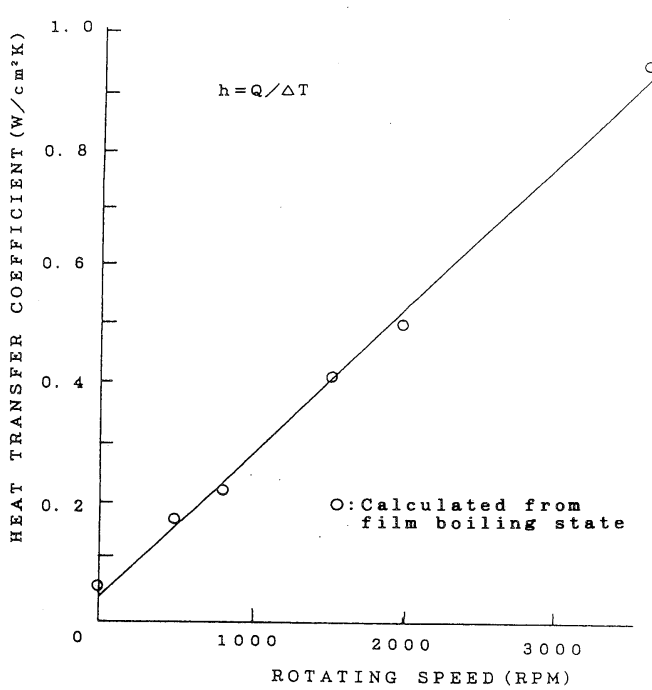

Fig. 6 Heat transfer coefficient versus rotating speed.

である。ヒータをはさんだ 1-2 間の電圧はヒータによ り常電導状態になっていることを示しているが，2-3, 2-4 間の電圧は完全に常電導状態になった場合に比べ 小さく，かつ両者は添ぼ等しい。これは 2-3 間のごく 一部だけが常電導状態になっていることを示してい

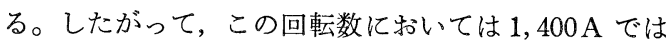
常電導相が伝播せず，一方超電導状態にも復帰しな い。したがって，最小云播電流にほ注等しいというこ とができる。Fig. 8 は伝播速度が零になる電流值を Fig. 5 から求めたものである。回転数が大きい注うが 最小伝播電流が大きくなっている。これは回転数が大 きい注ど熱伝達率が大きくなることによる。

Fig. 8 亿打いて実線は (1) 式に示す Dresner の伝 播速度の值を零として求めたものであり，破線は Maddock の等面積則により計算したものである ${ }^{6}$ 。計

低 温 工学 


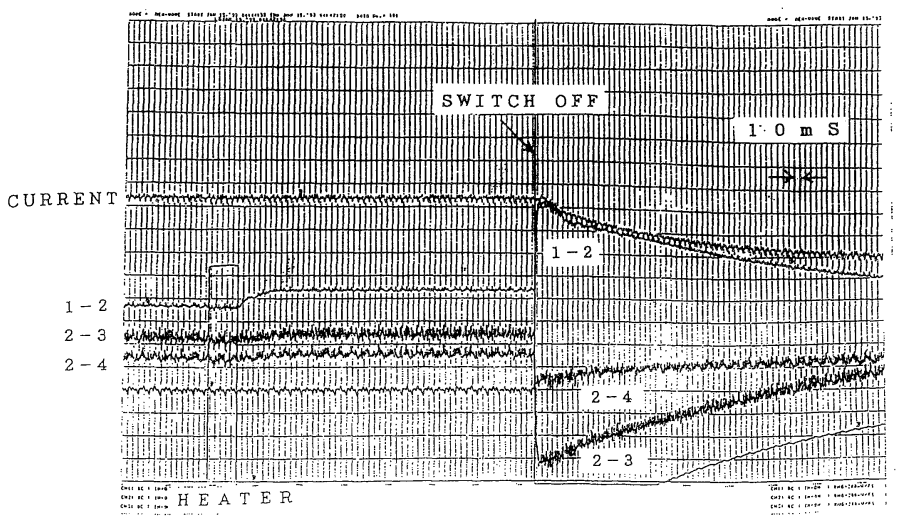

Fig. 7 Typical measured voltage profiles in case of the minimum propagating current.

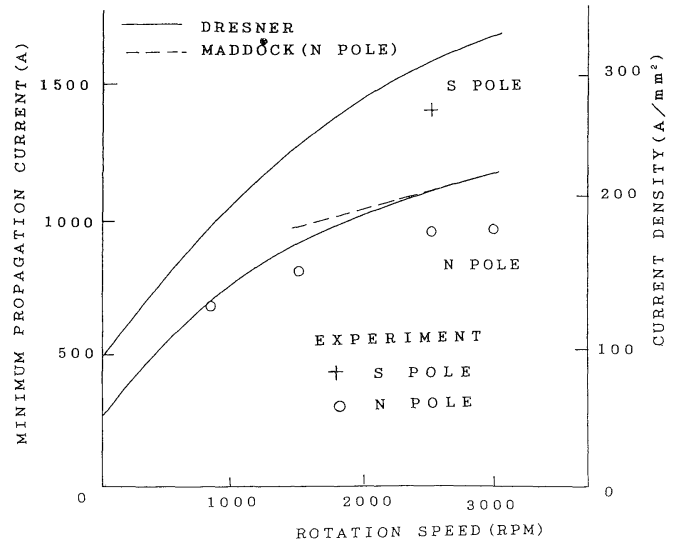

Fig. 8 Minimum propagating current versus rotating speed.

算に使用したへりウムの熱伝達特性は, 回転子マグネ ットのごく近傍に置かれた熱流束計測素子により測定 したものである。したがって導体表面と熱流束素子の 表面の違いなどを考慮すると計算に使用した熱流束の 值は必ずしも導体表面からの值と正確に一致するとは いえない。実測結果と計算結果にこの程度の差がある のはこのような理由であろう。な㧈 Maddock の等面 積則により計算した值と Dresner の式から計算した 值がずれている理由のひとつは Dresner の式から計 算する場合に用いた熱伝達特性の近似であるう。例党 ば（1）式から計算した最小伝播電流は, 核沸騰領域 に打ける冷却の效果が過小評価されているため低速度 の回転数では, Maddock 等面積則から計算した值の ほうが大きくなっている。しかし回転数が大きくなる につれ核沸騰領域に抢沙る熱伝達特性は膜沸騰領域に 特ける近似式に近づくため，両者はほぼ同じ值を示し

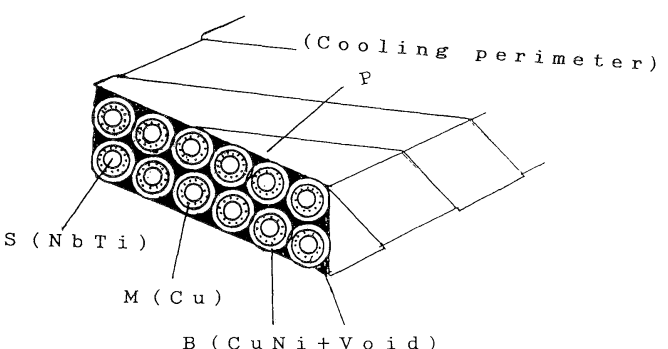

Fig. 9 Cross-section of the superconductor in consideration.

ている。以上の結果から最小伝播電流の值は Dresner の（1）式を用いて十分よい近似で推定できると考克 られる。

\section{3 最小伝播電流の電流密度についての理論的検 討}

最小伝播電流は熱櫌乱に対して安定な限界を与兄る 電流であり, 超電導発電機の界磁巻線の設計基準とし て使党る可能性がある。また, 発電機設㖕上の数字と して重要な電流密度は, $2,500 \mathrm{rpm}$ に扮汀る $\mathrm{S}$ 極の最 小伝播電流值 $1,400 \mathrm{~A}$ から計算すると $270 \mathrm{~A} / \mathrm{mm}^{2}$ （2.3 T）とかなり大き忘值となっていることも注目に 值する。実規模の発電機が経験する磁界 (5T) に招い てどの程度の電流密度が可能であるか, 最小伝播電流 の考光方に基づいて簡単な理諭検討を行ってみる。

最小伝播電流 $I_{\mathrm{mp}}$ は $(1)$ 式の $V_{\mathrm{p}}$ を零と拈くこと により（2）式のように表すことができる。

$$
I_{\mathrm{mp}}=\frac{-1+\sqrt{1+8 \alpha}}{2 \alpha} I_{\mathrm{c}}
$$

Fig. 9 亿示す断面を有する超電導体の最小伝播電流 の導体断面積に対する電流密度 $J_{\mathrm{mp}}$ は (3) 式のよう 


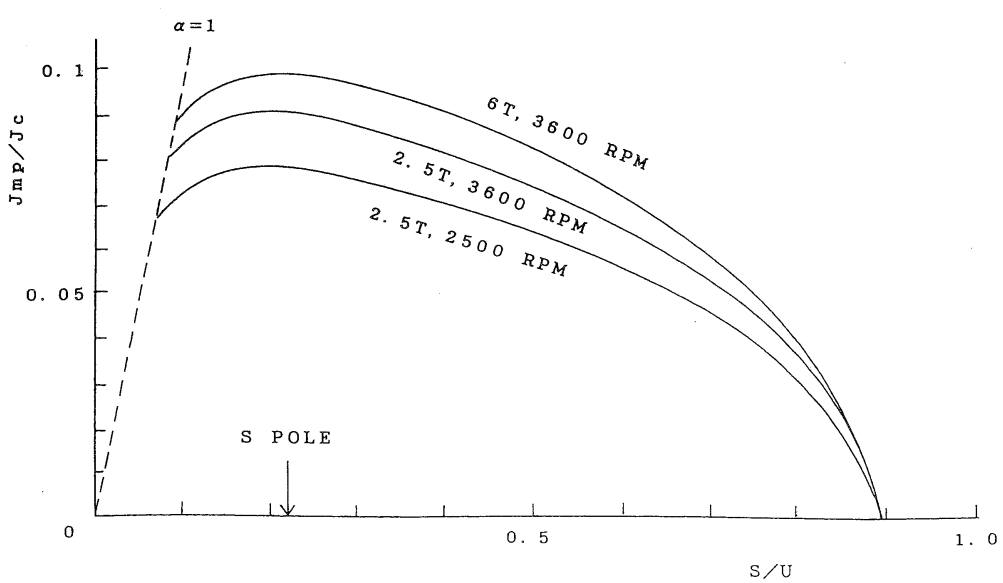

Fig. 10 Minimum propagating current dependence on the matrix metal composition.

になる。

$$
J_{\mathrm{mp}}=\frac{I_{\mathrm{mp}}}{U}
$$

ただし， $U=M+B+S$ 注導体の断面積, $M, B, S$ はそれぞれ安定化導体 (銅, アルミニウム等), 超電 導フィラメント間のカップリング遮断用金属 $(\mathrm{CuNi})$ ナボイド，拈よび超電導金属 ( $\mathrm{NbTi}$ ) である。

Uを用いて，（3）式よりMを消去すると（4）式の ようになる。

$$
\frac{J_{\mathrm{mp}}}{J_{\mathrm{c}}}=\frac{4 x}{1+\sqrt{1+m \frac{x^{2}}{1-\frac{B}{U}-x}}}
$$

ただし， $\rho_{\mathrm{s}}$ は安定化導体の抵抗率， $m=\left(8 J_{\mathrm{c}}^{2} \rho_{\mathrm{s}} / h\left(T_{\mathrm{c}}\right.\right.$ $\left.\left.-T_{0}\right)\right) \cdot(U / P), J_{\mathrm{c}}=I_{\mathrm{c}} / S, x=S / U$ である。導体の 形状が相似であれば $U / P$ は $\sqrt{U}$ に比例する。

いま，U,Pを一定とするとmは一定となる。した がって一定の条件下（磁界, 冷却等) 飞执いて同一断 面積Uを有する導体の $J_{\mathrm{mp}} / J_{\mathrm{c}}$ の值は (4) 式に沶い てxの值のみの関数として調べることができる。

Fig. 10 は Table 2 に示すS極の導体の $S$ とMの割 合のみをを変光た場合の $J_{\mathrm{mp}} / J_{\mathrm{c}}$ の変化を示したもの である。ただし導体の置かれた条件は図中に示したよ になっている。

Fig. 10 に扔いて破線は $\alpha=1$ と古る場合を表して いる。 $\alpha<1$ の領域（破線より $x$ が小さい領域）では Stekly の完全安定化条件を満たしているため最小伝 播電流を考学る必要はない。

Fig. 10 に打いて $x=0.888$ は $M$ を零, つまりボイ ドを除いた全断面積 $U$-Bを $S$ とした場合であり $J_{\mathrm{mp}} /$

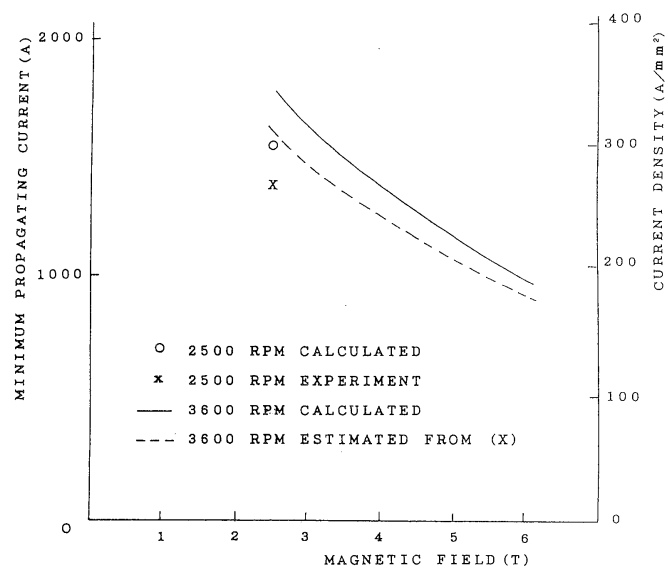

Fig. 11 The magnetic field dependence of the minimum propagating current.

J を大きくしていくと $J_{\mathrm{mp}}$ は大きくなっていく。しか し $x=0.2$ 付近で最大になり $S$ が小さくなるにつれ $J_{\mathrm{mp}} / J_{\mathrm{c}}$ す小さくなる。

$S$ 極に用いた導体の $x$ の值は 0.22 であり，汪ぼ $J_{\mathrm{mp}} / J_{\mathrm{c}}$ の最大值を与えていることがわかる。したが って，S 極と同じ面積を有する導体を用いた場合の最 小伝播電流の電流密度を最大にするための最適な $x$ の 值は 0.22 と固定して考光ることとする。また Fig. 10 に示す特性から $x=0.22$ として固定し, 外部磁界を 変えた場合の S 極の最小伝播電流を計算して Fig. 11 に示す。破線は実験で得られた $2,500 \mathrm{rpm}$ の值 (X 印）が $3,600 \mathrm{rpm}$ の回転数では実線で示した計算值 


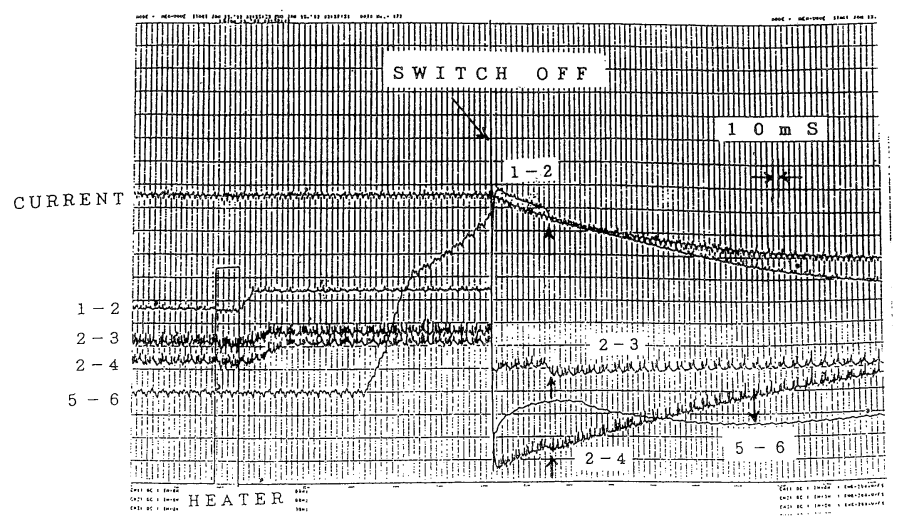

Fig. 12 A measured voltage profiles showing the effect of warm helium flow.

と同じ割合で磁界とともに減少すると仮定したもので ある。破線汇扔いては 5 T付近での電流密度が $200 \mathrm{~A} /$ $\mathrm{mm}^{2}$ となっている。実規模の発電機注抒いては回転 子マグネットの直径がさらに大きくなり，冷却特性が さらによくなることも期待され，200 $\mathrm{A} / \mathrm{mm}^{2}$ 以上の 電流密度が可能であることが推定される。

また，臨界温度の大きな $\mathrm{Nb}_{3} \mathrm{Sn} を$ 用い，安定化用 の常電導金属として銅占り電気抵抗の小さいアルミニ ウムを用いれば， $\alpha$ の值が小さくなるため，さらに高 電流密度化が可能であるう。

\section{4 ヘリウムの流れの影響}

ヘリウムの流れは巻線部の周囲側から中心部に向か っている。このため Fig. 1 亿示すよらな電圧タップを 取り付けているとヒータ部分から発生した常電導相部 の熱により暖められたへリウムまたは発生した気泡が 下流飞流れ，下流部の熱云達特性に影響を与兄る。

Fig. 12 はこのよらな影響を示した測定例である。ヒ 一タの卷いて西る区間 1-2，2-3，2-4の電压が上昇し た後に下流側の 5-6 間の電圧が上昇している。5-6 間 の電圧の変化を見ると 5-6 間全体が常電導状態になっ た後も電圧が上昇しているのがわかる。こ机に対して 1-2，2-3，2-4 の電壬は一定值化尗っている。この ことは 1-2, 2-3, 2-4 間では常電導状態になっても銅 の抵抗が大きく変わる温度までの温度上昇が起こって いないのに対し，5-6間では，より大きな温度上昇が 起こっていることを示している。これは 5-6 間と 1-2, 2-3，2-4間に流れてくるへリウムの状熊が異なり， 5-6 間は上流のへリウムの流れの影響を受けているた めと考光られる。電流遮断の直前では銅の抵抗值から 推定して $50 \mathrm{~K}$ 近くまで温度が上がっている。電流遮
断後の超電導状態への復㷌の様子にも似た現象が見ら れる。電流の減衰侍においていで示した時刻において， 1-2，2-3，2-4，5-6のそれぞれの区間が完全に超電導 状態に復㷌している。超電導状態へ復帰する電流の值 を此べると，1-2，2-3，2-4 間では添淁等しく 1,000A になっている。これに刘して 5-6間では 500A となっ ており，上流側の超電導状態復帰に比べ下流側の復帰 が浬れているのがわかる。

このような現象は冷媒の熱伝達率がいかに敏感に超 電導導体の安定性汇影響を与えているかを示すもので あり，したがってクェンチ後のマグネットの挙動の検 討にはこのようなへリウムの流れの影響も考慮する必 要があることを示している。

\section{4. 結言}

回転子マグネットの卷線の卷替学を行い，安宗性の 試験を行って以下のような結果を得た。

1）常電導相の伝播速度は最小伝播電流付近ではマ グネットの回転速度によって変わることが実験的に明 らかにされた。Dresner の伝播速度の理論式と本実験 結果は大体に扑いてょく一致した。

2）電流の減衰時に超電導状態が回復する様子が観 測された。このような測定結果から負の伝播速度を求 めることができた。これにより最小伝播電流の值がよ り正確に決めることができるようになった。

3）最小伝播電流の值をDresner の理論式拈よび Maddock の等面積則で計算した結果，ほ汸実験結果 をよく説明できることがわかった。これらの計算に必 要なへリウムの泠却特性化ついては今後より正確な数 值を明らかにしていく必要がある。 
40

4）本実験に用いた導体を仮定して，実規模発電機 が経験する 5 Tの磁界中に扣ける最小伝播電流の電流 密度を推定した結果 $200 \mathrm{~A} / \mathrm{mm}^{2}$ が可能であることが わかった。

5）常電導相が発生した場合へリウムが暖められ， その影響がへリウムの流れの下流側に起こる現象が観 測された。今後この現象がマグネット設計上の重要な 要素となるかどうか，上く検討していく必要がある。

以上に述べた結果と前回をでの試験結果を合わせる ことにより, 回転子マグネットの最小伝播電流拈よび 伝播速度等に与光る諸因子の影響がかなり明らかにさ れてきたといえる。ここでは超電導体に作用する擾乱 としてヒータを使用したが, 今後は変動磁界, 導体の
動き等の実際の擾乱を加えた状態に和ける安定性との 比較が重要である。この場合には冷媒の熱伝達率特性 が十分に把握されている必要がある。

\section{参考 文 献}

1）石井 格ら：低温工学 26 (1991) 311

2) 书口 登ら：低温工学 26（1991） 502

3) T. Onishi, et al.: Cryogenics 31 (1991) 664

4) K. Kaiho, et al.: Cryogenics 31 (1991) 668

5) L. Dresner: IEEE Trans Magn. MAG-15 (1979) 328

6) B.J. Maddock, et al.: Cryogenics 9 (1969) 261 